\title{
PENGARUH PENERAPAN METODE PEMBELAJARAN COLLABORATIVE PROBLEM BASED LEARNING (CPBL) TERHADAP KREATIVITAS ANAK DALAM BERMAIN KOMPUTER
}

\author{
PARWOTO \\ Fakultas Ilmu Pendidikan Universitas Negeri Makassar \\ Email:parwotounm@yahoo.com
}

\begin{abstract}
The problem continues to be the development of children's creativity experts talk of education of preschool children, especially regarding the optimization function of the right hemisphere as a function of the creativity and imagination of children. On the basis of this assumption, the development of creativity is very important in earnest in early childhood education, especially in early childhood This study aims to determine the effect of applying the method of collaborative problem-based learning to play computer creativity of children in kindergarten Dharmawanita Lotus Makassar. This research is a kind of experimental control group design and samples were taken through a multi-stage random sampling. The results showed that the children's creativity in playing computer games for children who attend the learning method CPBL included in the high category, while the children's creativity in playing computer games for a group of children who attend individual tutorial learning methods included in the medium category. No effect of the application of collaborative learning method of problembased learning to the creativity of children in kindergarten children play on the computer.
\end{abstract}

Keywords: CPBL methods, creativity, computer, kindergarteen

\begin{abstract}
Abstrak: Masalah pengembangan kreativitas anak terus menjadi pembicaraan para ahli pendidikan, khususnya pada pendidikan anak prasekolah, khususnya yang menyangkut pengoptimalan fungsi belahan otak kanan sebagai fungsi kreativitas dan imajinasi anak. Atas dasar asumsi ini, maka pengembangan kreativitas menjadi sangat penting digalakkan pada pendidikan anak usia dini, khususnya di PAUD. Penelitian ini bertujuan untuk mengetahui pengaruh penerapan metode collaborative problem based learning terhadap kreativitas bermain komputer anak di TK Dharmawanita Teratai Makassar. Penelitian ini adalah penelitian eksperimen jenis control group design dan sampel penelitian diambil melalui multi stage random sampling. Hasil penelitian menunjukkan bahwa kreativitas anak dalam bermain komputer bagi anak yang mengikuti metode pembelajaran CPBL termasuk dalam kategori tinggi, sedangkan kreativitas anak dalam bermain komputer bagi kelompok anak yang mengikuti metode pembelajaran tutorial individual termasuk dalam kategori sedang. Ada pengaruh penerapan metode pembelajaran collaborative problem based learning terhadap kreativitas anak dalam bermain komputer.
\end{abstract}

Kata Kunci: metode CPBL, kreativitas, komputer, early childhood

Dalam konteks pengembangan sumberdaya manusia, pendidikan anak usia dini, khususnya pendidikan anak Taman Kanak-kanak

(TK)

harus dilakukan melalui pemberian rangsangan pendidikan untuk 
membantu pertumbuhan dan banyaknya anggapan yang keliru perkembangan yang optimal. tentang fungsi media komputer bagi Berbagai kemampuan yang pendidikan anak TK. Pembelajaran teraktualisasikan beranjak dari komputer pada anak TK masih berfungsinya otak anak. Oleh karena terbatas kepada pengenalan itu dalam upaya pendidikan anak TK, keyboard, mouse, dan peralatan lain baikguru maupun orang tua dalam mengarahkan belajar anak perlu memperhatikan masalah yang terkait dengan pemenuhan kebutuhan psikologis, perkembangan inteligensi, emosional dan motivasi, serta pengembangan kreativitas anak.

Secara khusus dalam pembelajaran di TK sudah saatnya pengembangan kreativitas anak memperoleh perhatian sehingga dapat mengembangkan berfungsinya kedua belahan otak secara seimbang. Pembelajaran yang mengendalikan berfungsinya kedua belahan otak secara seimbang akan banyak membantu anak berprakarsa mengatasi dirinya, meningkatkan prestasi belajar sehingga mencapai kemandirian dan mampu menghadapi berbagai tantangan.

Belum berkembangnya kurikulum berbasis kreativitas, khususnya dalam pembelajaran komputer disinyalir masih serta fungsi komputer sebagai alat untuk bermain edu-game dan pengenalan bacaan dan bilangan. Untuk kepentingan pengembangan pembelajaran komputer berbasis kreativitas di TK, menuntut anak dapat menguasai aplikasi penggunaan software komputer sehingga dapat membantu anak-anak belajar dan bermain dengan software komputer yang sesuai dengan tingkat perkembangan dan jenis kompetensi yang hendak dikembangkan. Untuk itu, berkaitan dengan pengembangan kreativitas anak, maka baik guru maupun anak harus dapat memilih software yang dapat membantu mengembangkan kreativitas anak seperti aktivitas menggambar, mewarnai, mengadopsi, memodifikasi, dan mengkonstruksi gambar.

Berdasarkan latar belakang masalah di atas, maka dirumuskan masalah penelitian: (1) Bagaimana 
Pengaruh Penerapan Metode ... Parwoto

gambaran penerapan metode memperkenalkan gagasan bahwa collaborative problem based belajar adalah sebuah pengalaman learning $(C P B L)$ dalam peningkatan kreativitas anak dalam bermain computer pada TK Teratai Dharma Wanita UNM Makassar?; Bagaimana gambaran hasil yang dicapai (kreativitas) anak dalam bermain komputer antara kelompok anak yang menggunakan metode pembelajaran $C P B L$ dan kelompok anak yang mengikuti metode pembelajaran tutorial individual?, dan (3) Apakah ada terdapat perbedaan kreativitas bermain komputer antara kelompok anak yang menggunakan metode pembelajaran $C P B L$ dan kelompok yang menggunakan metode pembelajaran tutorian individual pada TK Teratai Dharma Wanita UNM Makassar?

\section{Metode Collaborative Problem}

\section{Based Learning}

Metode pembelajaran kolaboratif merupakan metode pembelajaran yang menerapkan paradigma baru dalam teori-teori belajar khususnya pembelajaran konstruktivisme yang dipelopori oleh Vigotsky. Vigotsky (1986) sosial. Pertama individu berpikir secara sendiri-sendiri membuat makna pribadi, kemudian mereka menguji hasil pemikirannya dalam dialog dengan yang lain untuk membangun pengertian yang didisusikannya (George W. Gagnon Jr. and Michelle Collay, 2001). Dengan gagasan ini, berarti anakanak secara bersama membangun pengertian secara kolektif dengan menggambarkan pemaknaan yang dibahasa dalam sebuah komunitas yang lebih luas. Hal ini diperkuat pendapat Thomas Kuhn (1996) yang menggambarkan bahwa sebuah proses sosial yang sangat mirip konstruksi pengetahuan pada sebuah dunia yang luas dalam The Structures of Scientific Revolutions. Ia menjelaskan bagaimana banyak teori yang eksis dalam abad silam yang pertama diajukan oleh individuindividu, lalu diperdebatkan oleh kelompok-kelompok yang mempelajari teori itu, dan akhirnya diterima komunitas sains internasional. 
Collaborative learning juga mendasarkan teori Piaget yaitu Construtivist Theory yang memperkenalkan dengan gagasannya Active Learning. Ia percaya bahwa siswa bekerja lebih baik jika mereka berpikir secara bersama dalam kelompok, merekam pemikirannya, dan menjelaskannya dengan mempresentasikan hasil karyanya (pameran) untu kelasnya. Mereka secara aktif mendorong dengan yang lain untuk berpikir bersama, mereka menjadi lebih tertarik dalam belajar (ibid). Mengenai keanggotaan dalam kelompok belajar, Gagnon dan Collay menyatakan bahwa anggota dalam sebuah kelompok lebih hidup (eksis) dalam belajar jika mereka bekerja dengan materi atau model untuk menjelaskan berpikirnya. Mereka terdorong secara fisik sama halnya secara mental dan membuat berpikirnya terlihat untuk yang lain. Anak akan lebih mengalami kemajuan melalui perasaan dan imajinasinya daripada melalui bahasa. Pergerakan dari pemaknaan pribadi untuk shared meaning menjadi pendorong ketika anak mengkonstruksi sebuah presentasi ulang berpikirnya.

Menurut Smith and Gregor (2004), ada tiga teori yang mendukung metode belajar kolaboratif (collaboratif learningmethod) yaitu teori kognitif, teori konstruktivisme sosial dan teori motivasi. Teori kognitif berkaitan terjadinya pertukaran konsep antar anggota dalam kelompok pada pembelajaran kolaboratif sehingga transformasi ilmu pengetahuan akan terjadi pada setiap anggota dalam kelompok. Pada teori konstruktivisme sosial terlihat adanya interaksi sosial antar anggota yang akan membantu perkembangan individu dan meningkatkan sikap saling menghormati pendapat semua anggota dalam kelompok. Teori motivasi teraplikasi dalam struktur pembelajaran kolaboratif karena pembelajaran tersebut akan memberikan lingkungan yang kondusif bagi seseorang untuk belajar, menambah keberanian semua anggota untuk memberi pendapat, dan menciptakan situasi saling memerlukan pada seluruh anggota dalam kelompok. 
Pengaruh Penerapan Metode ... Parwoto

Dalam belajar kolaboratif, tidak ada perbedaan tugas untuk masing-masing individu dalam kelompok, melainkan tugas itu adalah milik bersama dan diselesaikan secara bersama dan bukan dikotak-kotak menurut kecakapan belajar anak. Dengan demikian, dalam belajar kolaboratif penekanannya bagaimana cara agar anak dalam aktivitas belajar kelompok terjadi adanya kerja sama, interaksi, dan sharing of information. Tinsmann, Jones, Bakker, Fine, and Pierce (1990) membedakan Cooperative Learning dan Collaborative Learning sebagai berikut. Cooperative Learning a form of collaboration, is "working together to accomplish shared goals", Whereas collaborations happens in both small and large groups, cooperations refers primarily to small groups of student working together. Jadi, dalam pernyataan tersebut belajar kooperatif sebagai bentuk kolaboratif, yaitu bekerja bersama untuk terpenuhinya tujuan bersama. Kalau belajar kolaboratif dapat terjadi untuk kelompok kecil dan kelompok besar, sedangkan belajar kooperatif hanya menitik beratkan pada kelompok kecil di mana anggotanya bekerja bersama.

Reid (2004) menegaskan bahwa terdapat lima tahapan dalam mengembangkan collaborative problem based lerning yaitu Engagement, Exploration, Transformation, Presentation, and Reflection. Brandt menekankan adanya lima elemen dasar yang dibutuhkan agar kerjasama dalam proses pembelajaran dapat sukses yaitu: (1) Positive interdependence, Siswa harus percaya bahwa mereka adalah dalam proses belajar dan bahwa mereka peduli pada belajar anak yang lain; (2) Verbal, face-toface interaction, Siswa harus menjelaskan, berargumen, elaborasi, dan terikat terhadap apa yang mereka pelajari sekarang untuk mengikat apa yang mereka sebelumnya pelajari; (3) Individual accountability, Setiap anggota dalam kelompok harus realis bahwa mereka harus belajar; (4) Social skills siswa harus belajar dan diajar kepemimpinan, komunikasi, kepercayaan, membangun dan 
keterampilan memecahkan konflik;

5) Group processing, kelompok harus mampu menilai kebaikan apa yang mereka kerjakan secara bersama dan bagaimana mereka dapat melakukan secara lebih baik.

Metode pembelajaran $C P B L$ memiliki keunggulan dengan metode belajar mandiri. Menurut Slavin (Reid, 2004) keunggulan metode pembelajaran $C P B L$ adalah: (1) Belajar kolaboratif memotivasi siswa untuk melakukannya yang terbaik, (2) belajar kolaboratif memotivasi siswa untuk membantu siswa yang lain, dan (3) belajar kolaboratif secara signifikan meningkatkan prestasi siswa. Gagnon dan Collay (Reid, 2004) mengungkapkan bahwa "Anggota suatu kelompok akan lebih terbuka dalam belajar jika mereka belajar dengan sejumlah materi atau model untuk menjelaskan berpikir mereka.

Pembelajaran kolaboratif berbasis masalah merupakan sebuah pendekatan pembelajaran yang menyajikan masalah kontekstual sehingga merangsang peserta didik untuk belajar bersama. Dalam kelas yang menerapkan pembelajaran berbasis masalah, peserta didik bekerja dalam tim untuk memecahkan masalah dunia nyata (real world).

Langkah-langkah pembelajaran berbasis masalah adalah:

1) Konsep Dasar (Basic Concept)

Fasilitator memberikan konsep dasar, petunjuk, referensi, atau link dan skill yang diperlukan dalam pembelajaran tersebut. Hal ini dimaksudkan agar peserta didik lebih cepat masuk dalam atmosfer pembelajaran dan mendapatkan 'peta' yang akurat tentang arah dan tujuan pembelajaran

2) Pendefinisian Masalah (Defining theProblem)

Dalam langkah ini fasilitator menyampaikan skenario atau permasalahan dan peserta didik melakukan berbagai kegiatan brainstorming dan semua anggota kelompok mengungkapkan pendapat, ide, dan tanggapan terhadap skenario secara bebas, sehingga dimungkinkan muncul berbagai macam alternatif pendapat

3) Pembelajaran Mandiri (Self Learning) 
Pengaruh Penerapan Metode ... Parwoto

Peserta didik mencari berbagai sumber yang dapat memperjelas isu yang sedang diinvestigasi. Sumber yang dimaksud dapat dalam bentuk artikel tertulis yang tersimpan di perpustakaan, halaman web, atau bahkan pakar dalam bidang yang relevan.

Tahap investigasi memiliki dua tujuan utama, yaitu: (1) agar peserta didik mencari informasi dan mengembangkan pemahaman yang relevan dengan permasalahan yang telah didiskusikan di kelas, dan (2) informasi dikumpulkan dengan satu tujuan yaitu dipresentasikan di kelas dan informasi tersebut haruslah relevan dan dapat dipahami.

4) Pertukaran Pengetahuan

\section{(Exchange knowledge)}

Setelah mendapatkan sumber untuk keperluan pendalaman materi dalam langkah pembelajaran mandiri, selanjutnya pada pertemuan berikutnya peserta didik berdiskusi dalam kelompoknya untuk mengklarifikasi capaiannya dan merumuskan solusi dari permasalahan kelompok. Pertukaran pengetahuan ini dapat dilakukan dengan cara peserrta didik berkumpul sesuai kelompok dan fasilitatornya.

5) Penilaian (Assessment)

Penilaian dilakukan dengan memadukan tiga aspek pengetahuan (knowledge), kecakapan (skill), dan sikap (attitude). Penilaian terhadap kecakapan dapat diukur dari penguasaan alat bantu pembelajaran, baik software, hardware, maupun kemampuan perancangan dan pengujian.

Hal ini penting dalam pembelajaran anak TK, karena pengetahuan awal, kesalahan konsepsi sering terjadi, karena adanya sumber dari media dan budaya yang berbeda-beda. Di antara anak akan saling melengkapi pengertian bila diantara mereka berkolaboratif. Memang sering terjadi dalam moment tertentu, tidak ada anggota kelompok anak yang mengerti suatu konsep atau definisi yang dikaitkan dengan pengelaman mereka. Jika terjadi hal demikian, seorang guru harus dapat mencarikan jalan keluar arus persepsi, berbagai konstruksi dan miskonsepsi anak. Guru harus memahami pengetahuan aktual apa yang harus dimiliki dan dipikirkan 
anak sebelum diperkenalkan pada belajar baru (new learning).

$$
\text { Metode kolaboratif }
$$
merupakan metode di mana anakanak bekerjasama dalam kelompok kecil untuk mencapai tujuan yang sama. Alasan anak diharapkan dapat belajar berkelompok, karena pada dasarnya pengelompokan bukanlah tujuan utama, melainkan bagaimana pengetahuan dikonstruksi oleh individu anak melalui belajar kelompok. Pengelompokan anak, menurut konstruktivisme merupakan salah satu strategi yang dianjurkan sebagai cara anak untuk saling berbagi pendapat, berargumentasi, dan juga mengembangkan berbagai alternatif pandangan dalam upaya konstruksi pengetahuan oleh individu anak. Metode belajar kolaboratif ini dapat digunakan pada semua mata pelajaran terutama yang memungkinkan terjadinya sharing of information di antara anak didik. Dalam belajar kolaboratif, anak-anak bekerja sama dalam kelompok kecil untuk mencapai tujuan yang sama.

Dalam kegiatan belajar kolaboratif, di antara anak dalam kelompok kecil bekerja sama menyelesaikan masalah yang sama, dan bukan secara individual. Ukuran pengelompokan dalam pembelajaran sangat penting untuk menentukan lingkungan di mana aktivitas belajar dilangsungkan. Walberg menggambarkan empat pola interaksi dalam kelompok dalam 4 variasi ukuran kelompok yaitu: 1) twoperson group (tutoring), 2) small group (interactive recitation; discusion), 3) small or large group (recitation), and 4) large group (lecture).

\section{Kreativitas Bermain Komputer}

Ada beberapa pertimbangan untuk memilih software mana yang cocok bagi anak-anak sesuai dengan pendapat Dodge dan Cokler yaitu: (1) kecocokan usia. Agar sesuai dengan perkembangan, software harus cocok dengan tingkat keterampilan yang dimiliki anak. Beberapa software yang dipasarkan untuk anak prasekolah meminta kecakapan kognitif, kemampuan berpikir abstrak, yang di luar tingkat perkembangan pada kelompok usia; (2) Kontrol anak. Mencari software yang anak-anak dapat gunakan secara bebas. (sejumlah program 
Pengaruh Penerapan Metode ... Parwoto

disediakan bagi anak-anak untuk dapat memilih software yang terstruktur yang lebih tinggi. Program yang baik mendorong anakanak untuk melompat, memutuskan aktivitas yang akan dilakukan, dan menjelajah secara bebas;

Membuka dan mengakhiri. Software yang baik akan secara aktif melibatkan anak-anak dalam penjelajahan. Tujuan bermain komputer bagi anak-anak untuk belajar dari proses sampai kepada produk atau jawaban yang benar. Produk software yang cocok bagi anak adalah software yang memberikan kesempatan kepada anak untuk menjadi kreatif dan memecahkan masalah (solve problem); (4) Multisensory learning. Program yang baik untuk pola variasi belajar anak-anak dan melibatkan anak-anak untuk manipulasi "objek" dua dimensi dan untuk menerima tanda dan balikan kedua visual dan auditori, yaitu Flexibility. Dalam kelompok anak prasekolah akan ditemukan tingkatan perkembangan, sejumlah produk software dapat diatur secara variasi menurut tingkat kesulitan dan untuk mengontrol corak sesuai tingkat kecepatan program dan tingkatan suara. (5) Empowerment (penguasaan). Program software yang efektif menciptakan lingkungan belajar yang "no failure", sehingga semua anak mengalami kesuksesan. Dengan sejumlah pertimbangan di atas, maka jika guru dapat mempertimbangkan software seperti yang dikemukakan di atas, guru akan dapat meyakini bahwa program itu akan sesuai dan pantas untuk dikembangkan dalam pembelajaran di kelas.

Menurut Craft (2008) bahwa dalam pengembangan kreativitas anak juga dimasukkan 'desain dan teknologi'. Desain dan teknologi pada intinya perlu bagi anak untuk berpikir secara kreatif, melakukan eksperimen, terbuka pada kemungkinan, untuk mengambil resiko, menjadikan siap mengkombinasikan cara pandang lama dengan cara pandang baru, menjadi siap melihat situasi atau persoalan dengan cara yang berbeda, untuk mencari inovasi, untuk menjadi banyak akal"

Desain dan teknologi memerlukan intuisi, orientasi spasial, 
kecakapan, keahlian, emosi, ekspresi (semua merupakan operasi belahan otak kanan), juga bahasa, urutan, operasi logika dan matematika. Penting secara partikular untuk memberi anak ruang mengakses fungsi belahan otak kanan, dengan memberikan kesempatan untuk memunculkan dan mengkasifikasi ide-ide melalui kerja sama, diskusi, juga pembuatan model, sketsa, lukisan, konstruksi kotak-kotak, melalui teknologi informasi yang menggambarkan dan mendesainkan paket.

Bermain komputer bukan proses yang sama dengan kreativitas, tetapi di dalamnya terdapat beberapa program di mana anak dapat bermain yang akan membawa anak kepada kreativitas. Hal ini sesuai dengan pendapat Pepler bahwa "Terdapat beberapa peristiwa yang mana anak yang memiliki banyak pengalaman, termasuk respon-respon tidak biasa (sebagai contoh, menggunakan objek permainan yang tidak diatur (nonstructured) dan dengan beragam tujuan (multiple-purpose) adalah lebih kreatif dalam tugas-tugas lain".
Atas dasar pendapat ini berarti bermain komputer memiliki imitasi, convergent atau 'selera' netral yang kuat kelihatannya justru membantu perkembangan kreativitas karena anak banyak melakukan permainan eksperimental, atau apa yang disebut 'permainan penuh kemungkinan'. Dengan demikian, bermain komputer tidak harus dilakukan secara sendiri-sendiri dalam sebuah laboratorium tertutup, akan tetapi dapat pula dilakukan secara berkelompok. Justru bila bermain komputer dilakukan secara berkelompok akan sangat membantu perkembangan bahasa dan berpikir anak, karena di antara mereka saling komunikasi, interaksi, dan sharing of information. Dengan demikian implikasi dalam praktek pembelajaran komputer bahwa untuk mengembangkan kreativitas, maka bermain komputer yang dilakukan secara kolaboratif lebih baik daripada jika permainan itu dilakukan secara individual.

Bermain kreatif melalui media komputer bagian yang tidak dapat dipisahkan dari dunia anakanak. Agar guru dapat mengemas 
aktivitas bermain anak-anak maka guru perlu mengetahui seluk beluk bermain kreatif melalui media komputer, termasuk di dalamnya bagaimana menyediakan alat bermain kreatif yaitu software komputer kreatif. Yang dimaksud software komputer kreatif adalah semua software komputer yang apabila digunakan oleh anak dapat mengembangkan motivasi berkreasi, kemampuan memecahkan masalah, dan perkembangan imajinasi anak. Media bermain kreatif dalam komputer berfungsi untuk mengenal dunia dan kekuatan maupun kelemahan diri anak. Dengan media komputer, anak secara aktif melakukan kegiatan bermain eksplorasi dan eksperimentasi dengan menggunakan imajinasi dan kreativitasnya dengan memanfaatkan segala pengalaman masa lalu yang telah dimilikinya. Aktivitas bermain komputer yang menyenangkan akan meningkatkan aktivitas sel otak mereka. Keaktifkan sel otak akan membantu memperlancar proses pembelajaran anak khususnya pengembangan kreativitasnya.
Berdasarkan kajian pustaka, kajian penelitian yang relevan, dan kerangka berpikir yang telah diuraikan di atas, maka dapat dinyatakan hipotesis penelitian adalah "Kreativitas anak dalam bermain computer bagi kelompok anak yang menggunakan metode pembelajaran collaborative problem based learning lebih baik dari pada kelompok anak yang menggunakan metode tutorial individual.

\section{METODE PENELITIAN}

Penelitian ini dilaksanakan di Taman Kanak-kanak Teratai UNM Makassar, di Makassar, Jl. Bontolangkasa, Makassar. Penentuan tempat tersebut dengan pertimbangan bahwa TK tersebut memiliki populasi anak yang besar yaitu 268 anak yang tersebar dalam 8 kelas dan TK tersebut telah mengembangkan program pembelajaran komputer dengan fasilitas laboratorium komputer yang memadai (memiliki fasilitas 35 unit komputer) lengkap dengan software yang edu-game dan creative-learning yang dirancang oleh Lembaga Pendidikan Komputer (LEC) Makassar yang dikelola oleh 
guru yang berspesifikasi sarjana Teknologi Informatika.

Jenis penelitian ini adalah penelitian eksperimen semu (quasi eksperiment). Alasan dipilihnya jenis penelitian ini karena sifatnya yang implementatif terhadap metode pembelajaran yang sudah ada (telah dikembangkan). Metode pembelajaran yang telah ada dan yang akan diimplementasikan adalah metode pembelajaran $C P B L$. Implementasi metode pembelajaran $C P B L$ pada anak TK diterapkan di TK Teratai Dharmawanita UNM.

Desain penelitian ini menggunakan rancangan control group design . Pemilihan ini disesuaikan dengan data yang diharapkan ada perbedaan kreativitas anak melalui model pembelajaran CPBL sebagai variable bebas (yang berpengaruh). Dalam penelitian ini menggunakan dua variabel, yakni variabel bebas dan variabel terikat. Variabel bebas adalah model pembelajaran CPBL. Sedangkan variabel terikat adalah kreativitas anak dalam bermain komputer.

Pengambilan sampel pada penelitian ini dilakukan dengan tekhnik multi stage random sampling. Perlakuan yang dipakai dalam penelitian ini ditinjau dari empat aspek, yakni: (1) materi pembelajaran, (2) strategi pembelajaran Collaborative Problem Based Learning (CPBL), prosedur dan waktu pelaksanaan, dan (4) evaluasi. Ketiga aspek tersebut dapat diuraikan sebagai berikut:

\section{Materi pembelajaran}

Materi perlakuan adalah materi pembelajaran CPBL. Dalam bermain kreatif, yang diberikan pada kelompok eksperimen. Materi pelajaran ini diberikan sebanyak enam kali pertemuan dengan alokasi waktu yang telah disepakati oleh guru kelas. Materi bermain dalam metode CPBL meliputi bermain yang menggunakan fasilitas software figural dalam program accessories paint.

Dalam proses pengembangan bermain kreatif mengacu pada pendapat Wallas melalui empat tahap yang berlangsung sebagai berikut:

\section{a. Tahap persiapan (preparation)}

Pada tahap ini, ide itu datang dan timbul dari berbagai kemungkinan. 
Pengaruh Penerapan Metode ... Parwoto

Pada tahap ini, anak diberikan stimuli berupa hasil-hasil karya anak didik yang ada pada tahun ajaran sebelumnya. Anak diminta untuk mengamati, mendiskusikan dan menyempurnakan karyanya.

\section{b. Tahap inkubasi (incubation)}

Dalam tahap ini, secara emosional anak tidak disibukkan dengan permasalahan dan proses berpikir tentang apa yang telah diamati atau diselidiki. Kondisi anak tersebut dibuat rileks dengan mengalihkan perhatian dan pandangan menuju diperolehnya solusi atau petunjuk untuk produk kreatif. Pada tahap inkubasi ini, ditandai dengan rileksasi usaha mengambil topik atau tema baru sehingga diperoleh kemajuan atau menuju pemahaman baru. Hal ini merupakan aktivitas asimilasi atau transformasi informasi yang diperoleh pada tahap persiapan yang telah terjadi. Pada tahap ini latihan diintensifkan untuk memudahkan "perembetan", "perluasan", dan pendalaman ide dengan fokus tema yang dimunculkan dari anak itu sendiri.

\section{c. Tahap iluminasi (Illumination)}

Pada tahap ini merupakan tahap penemuan saat inspirasi yang tadi diperoleh, dikelola, digarap kemudian menuju kepada pengembangan pada suatu hasil, yaitu produk bermain kreatif melalui ciptaannya sendiri. Misalnya mencap gambar batang dengan pelepah pisang sehingga menjadi satu pepohonan yang rindang. Pada tahap ini anak dapat melakukan komunikasi dengan teman atau anggota kelompok lain untuk mendapatkan masukan demi penyempurnaan hasil kreatifnya sendiri.

\section{d. Tahap verifikasi (verification)}

Pada tahap ini, anak melakukan perbaikan atas masukan, kritik dan saran dari orang lain (teman, kelompok lain atau guru). Untuk menyempurnakan produk kreatifnya. Pada tahap ini anak dilatih berelaborasi terhadap kreativitas melalui media figural bermain computer.

\section{Strategi pembelajaran}

Perlakuan terhadap kelompok anak yang diberi perlakuan 
pembelajaran dengan model keempat, kelima dan keenam selama pembelajaran CPBL dan model enam hari.

pembelajaran konvensional (tutorial Evaluasi

individual) dilaksanakan dengan Evaluasi dilakukan secara individual materi/pokok bahasan yang sama, selain melalui pengamatan proses jumlah pertemuan tatap muka dan dan juga terhadap produk kreatif lama waktu tes. Namun dalam hal pelaksanaan yang berbeda. Yaitu kelompok eksperimen dengan perlakuan model pembelajaran CPBL dan kelompok kontrol dengan model pembelajaran konvensional (tutorial individual).

\section{Prosedur dan waktu pelaksanaan}

Pemberian perlakuan terhadap kelompok $\mathrm{A}_{1}$ dan $\mathrm{A}_{2}$ dalam penelitian ini, secara rinci prosedurnya sebagai berikut:

Pertemuan pertama; kelompok $\mathrm{A}_{1}$ diberi perlakuan dengan model pembelajaran CPBL, dan pertemuan kedua pada kelompok $\mathrm{A}_{2}$ diberi perlakuan dengan model pembelajaran konvensional. Tetapi bahan dan materi yang sama. Pada setiap hasil karya anak didik dinilai oleh peneliti kemudian peneliti melakukan pengamtan kreativitas anak dalam bermain komputer secara individu kepada anak didik. Begitu pula dengan pertemuan ketiga, anak dalam bermain figural komputer. Penilaian yang berpedoman pada kriteria yang telah ditetapkan sebagaimana lampiran 1 . Kriteria penilaian dikembangkan dalam 5 skala dengan mengembangkan komponenkomponen yang harus dipenuhi setiap aktivitas bermain kreatif. Bila anak memenuhi 5 komponen dalam aktivitas bermain kreatif pada setiap butir maka anak itu memperoleh skor 5.

Dengan demikian, skor tertinggi yang diperoleh oleh setiap anak pada akhir pembelajaran dapat mencapai 100 dan skor terendah 20 .

Data kreativitas bermain dianalisis dengan teknik statistik deskriptif dan statistik inferensial. Statistik deskriptif digunakan untuk deskripsi data, sedangkan statistik inferensial digunakan untuk menguji persyaratan analisis data dan menguji hipotesis penelitia 
Pengaruh Penerapan Metode ... Parwoto

Data tentang kreativitas anak

\section{HASIL PENELITIAN DAN PEMBAHASAN}

Dari hasil pengamatan proses bermain kreatif melalui figural accessories paint pada software komputer, diperoleh skor kreativitas anak dalam bermain komputer. Sesuai dengan perlakuan yang diberikan, maka masing-masing kelompok anak diberi perlakuan melalui model pembelajaran CPBL dan begitu pula sebaliknya anak kelompok pembanding konvensional tidak diberi perlakuan CPBL. dalam bermain komputer bagi kelompok anak yang mengikuti model pembelajaran konvensional, secara teoretik memiliki rentang skor 20-100, artinya skor maksimum yang dapat diperoleh anak adalah 100 dan skor minimum adalah 20, akan tetapi secara empirik skor maksimum yang diperoleh anak adalah 78 dan skor minimum adalah 59, dengan rerata 68.92 varians 29.16 dan simpangan baku 5.4 .

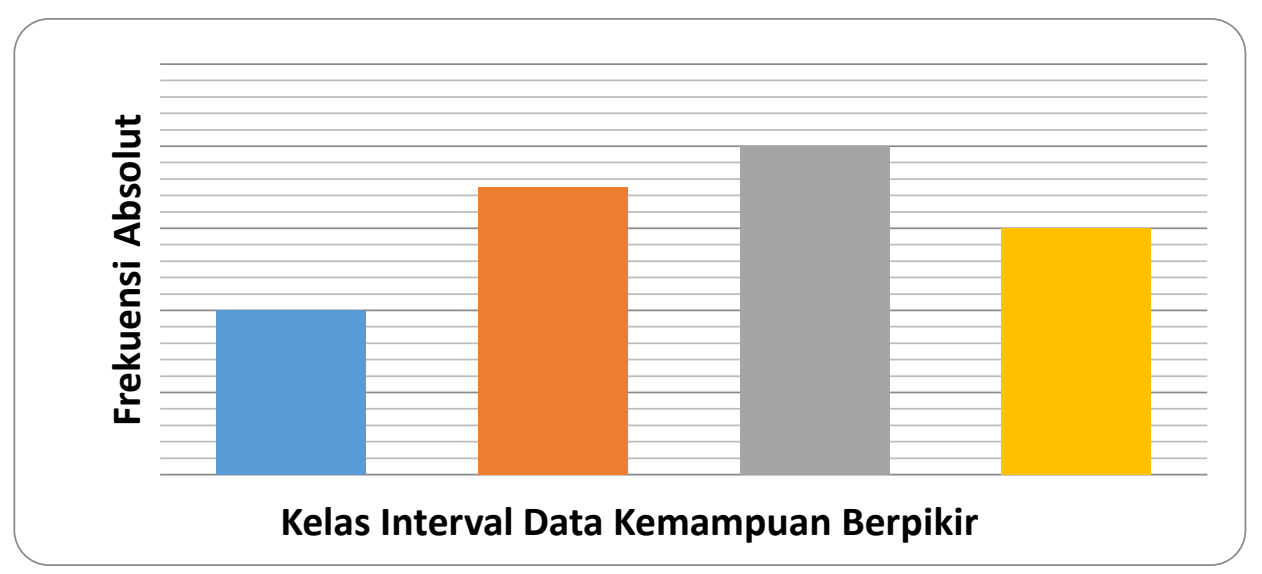

\section{Grafik 1}

Kelas Interval dara dan kemampuan berpikir

Distribusi frekuensi skor interval masing-masing dalam kemampuan berpikir bagi kelompok frekuensi absolut dan frekuensi anak yang mengikuti model relatif. Frekuensi tertinggi terletak pembelajaran konvensional, dapat pada kelas interval 72-76 dengan diklasifikasikan ke dalam 4 kelas 
frekuensi absolut 8 dan frekuensi relatif 32 .

Data tentang kreativitas bagi kelompok anak yang mengikuti model pembelajaran CPBL, secara teoretik memiliki rentang skor 20100 , artinya skor maksimum yang dapat diperoleh anak adalah 100 dan skor minimum adalah 20, akan tetapi secara empirik skor maksimum yang diperoleh anak adalah 81 dan skor minimum adalah 62, dengan rerata 71.92 varians 31.827 dan simpangan baku 5.6415.

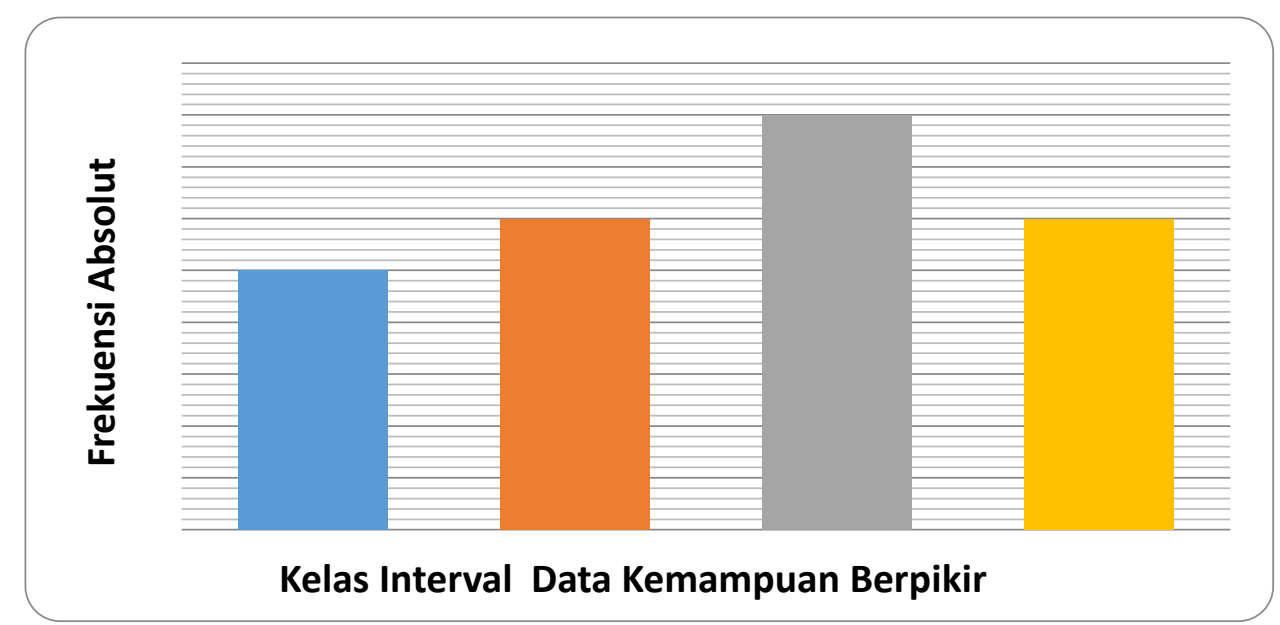

Grafik 2

Kelas Interval dara dan kemampuan berpikir

Distribusi frekuensi skor kreativitas bermain computer bagi kelompok anak yang mengikuti model pembelajaran CPBL, dapat diklasifikasikan ke dalam 4 kelas interval masing-masing dalam frekuensi absolut dan frekuensi relatif. Frekuensi tertinggi terletak pada kelas interval 72-76 dengan frekuensi absolut 8 dan frekuensi relatif 32 .

\section{Uji Asumsi}

Hipotesis penelitian diuji dengan menggunakan uji normalitas varians terhadap data yang telah dikumpulkan. Uji normalitas dilaksanakan untuk mengetahui apakah sampel penelitian berasal dari populasi yang berdistribusi normal. Sedangkan uji homogenitas dilaksanakan untuk mengetahui apakah data penelitian yang telah dikumpulkan berasal dari populasi yang homogen. 
Pengaruh Penerapan Metode ... Parwoto

\section{Uji Normalitas}

Uji normalitas dilakukan terhadap skor kreativitas anak dalam bermain komputer dari masingmasing kelompok perlakuan, yang terdiri dari dua kelompok data yang diuji normalitas distribusinya dilakukan dengan uji Lilliefors.

\section{Berdasarkan rancangan} eksperimen, maka ada dua kelompok data, yaitu: (1) kreativitas anak dalam bermain computer untuk kelompok anak yang mengikuti model pembelajaran CPBL dan (2) kreativitas dalam bermain computer untuk kelompok anak yang mengikuti model pembelajaran konvensional.

Hasil perhitungan dan uji signifikansi indeks normalitas (harga Lilliefors) secara keseluruhan disajikan pada tabel sebagai berikut:

Tabel 1

Rangkuman hasil uji normalitas data kreativitas anak dalam bermain computer

\begin{tabular}{lllll}
\hline Kelompok Data & $\mathrm{N}$ & $\mathrm{L}_{\mathrm{h}}$ & $\mathrm{L}_{\mathrm{t}}(\boldsymbol{\alpha}=0.05)$ & Keterangan \\
\hline $\begin{array}{l}\text { 1. Kelompok } \\
\mathrm{A}_{2}\end{array}$ & 25 & 0.1304 & 0.173 & Normal \\
$\begin{array}{l}\text { 2. Kelompok } \mathrm{A}_{1} \\
25\end{array}$ & 0.1643 & 0.173 & Normal \\
\hline
\end{tabular}

Keterangan:

$\mathrm{A}_{1}=\quad$ Kelompok anak yang mengikuti pembelajaran melalui metode pembelajaran CPBL

$\mathrm{A}_{2}=\quad$ Kelompok anak yang memiliki kreativitas dalam bermain computer yang mengikuti pembelajaran melalui model pembelajaran konvensional

Tabel di atas menunjukkan bahwa harga Lilliefors hitung $\left(\mathrm{L}_{\mathrm{h}}\right)$ pada masing-masing kelompok lebih kecil dari harga Lilliefors table $\left(\mathrm{L}_{\mathrm{t}}\right)$. Dengan demikian, dapat disimpulkan bahwa sampel penelitian ini berasal dari populasi yang berdistribusi normal.

\section{Uji homogenitas varians pada dua kelompok (A1 dan} A2)

Hasil perhitungan menunjukkan bahwa varians terbesar dalam kelompok ini adalah 31.827 dan varians terkecil adalah 29.16. Indeks homogenitas varians antara kedua 
kelompok yang diuji $\left(F_{h}\right)$ sebesar 1.091 sedangkan $\quad F_{t} \quad\left(\alpha_{0.05: 24,24}\right)$ adalah 1,71. Hal ini menunjukkan bahwa $F_{h} 1.091$ lebih kecil dari $F_{t}$ 1.71 yang berarti $\mathrm{H}_{0}$ diterima. Artinya kedua kelompok yang diuji yaitu kelompok $\mathrm{A}_{1}$ dan $\mathrm{A}_{2}$ adalah homogen, dengan kata lain kedua kelompok yang diuji tersebut berasal dari populasi yang homogen.

Hasil perhitungan dengan menggunakan uji hipotesis-t terhadap dua kelompok yang menjadi sampel penelitian ditemukan $\mathrm{t}=21.213$ dan harga $\mathrm{df}=24$ dengan taraf signifikan 0.000. Ini berarti hasil analisis menunjukkan adanya perbedaan. Olehnya itu, dilanjutkan lagi dengan Uji Lanjut dengan membandingkan besaran rata-rata dua kelompok yang diuji. Ternyata, rata-rata dari kelompok anak yang mengikuti model pembelajaran bermain kreatif sebesar 71.92, sedangkan rata-rata dari kelompok anak yang mengikuti model pembelajaran konvensional sebesar 68.92 (71.92> 68.92). Kesimpulan: pembelajaran yang menggunakan model pembelajaran bermain kreatif lebih efektif daripada pembelajaran yang menggunakan model pembelajaran konvensional.

Dalam penelitian ini ditemukan bahwa terdapat perbedaan kreativitas anak dalam bermain computer untuk kelompok anak yang menggunakan metode pembelajaran CPBL dan kelompok anak yang menggunakan metode pembelajaran tutorial individual. Hal ini dibuktikan dengan menggunakan uji homogenitas varians yang diperoleh harga $F_{\text {hitung }} 1.091$ yang ternyata signifikan.

Dalam hal ini, rerata skor kreativitas anak dalam bermain komputer bagi kelompok anak yang menggunakan metode pembelajaran CPBL lebih tinggi dibandingkan dengan rerata skor kreativitas anak untuk kelompok anak yang mengikuti metode pembelajaran tutorial individual.

Hal ini disebabkan karena model pembelajaran CPBL lebih memberi kesempatan kepada anak untuk melakukan sharing pengalaman dan kecakapan bermain kreatif dalam mengembangkan potensi intelek-tualnya dalam kegiatan bermain kreatif yang 
dikembangkan secara bersama.

Model pembelajaran konvensional menitikberatkan pembelajaran pada kerja individual bagi masing-masing anak sehingga kecakapan, pengalaman dan pengembangan intelektual berdasarkan perkembangannya sendiri. Hal ini disebabkan model pembelajaran konvensional hanya mengaktifkan satu belahan otak saja, yaitu belahan otak kiri dan menggunakan hanya sebagian kecil intelegensiintelegensi yang ada pada anak didik. Metode pembelajaran CPBL ikut mengaktifkan otak kanan dan mengikutsertakan intelegensiintelegensi lain yang dilakukan secara bersama yang tidak digunakan dalam metode pembelajaran konvensional. Metode pembelajaran CPBL menempatkan anak didik sebagai subjek belajar, artinya anak didik berperan aktif dalam proses belajar dengan cara menggali pengalaman sendiri; sedangkan dalam metode pembelajaran tutorial individual anak didik ditempatkan sebagai objek belajar yang berperan sebagai penerima informasi secara pasif.

\section{KESIMPULAN}

Kreativitas anak dalam bermain komputer bagi anak yang mengikuti metode pembelajaran CPBL termasuk dalam kategori tinggi, sedangkan kreativitas anak dalam bermain komputer bagi anak yang mengikuti metode pembelajaran tutorial individual termasuk dalam kategori sedang.

Ada pengaruh penerapan metode pembelajaran collaborative problem based learning terhadap kreativitas anak dalam bermain komputer pada anak TK Teratai Dharmawanita UNM Makassar.

Berdasarkan simpulan di atas, maka disarankan hendaknya guruguru menerapkan metode pembelajaran CPBL dalam setiap pembelajaran dengan cara menyediakan sarana bermain dan memberikan kebebasan anak bereksplorasi secara bersama dengan tetap mengembangkan keterampilan individual.

Kepada pemegang kebijakan di TK agar membudidayakan pengem-bangan metode pembelajaran CPBL bermain kreatif 
berbasis komputer dalam setiap pembelajaran, khususnya dalam pengembangan kemampuan berpikir kreatif atau berpikir divergen anak.

\section{DAFTAR PUSTAKA}

$\mathrm{V}=$ Austin Ann E. and Baldwin Roger G.. Faculty Collaboration, Enhancing the Quality of Scholarship and Teaching. Washington:ASHE Publisher. 2009.

Bloomberg Maton, Creativity: Theory and Research. New Haven. Conn. 2008

Catherine \& Glenn De Padua. Teaching Children, Computer Literacy. Jakarta: Elek Media Komputindo. 2009.

Catron Carol E, Allen Jan. Early childhood Curriculum A Creative Play Model. Meril, New Jersey: Printice-hall, 2010.

Craft Anna. Me-refresh Imajinasi \& Kreativitas Anak-anak. (Terjemahan oleh Chaerul Annam). Depok: Cerdas Pustaka, 2010.

Dodge Diane Trister, Colker J. Laura. The Creative Curriculum for Early Childhood, Teaching Strategis Co: Washington DC., 2009.

Gagnon Jr. George W., Collay Michell. Designing for

Gokhale, Anuradha A. Collaborative Learning Enchance Critical Thinking.

(http/scholar.lib.vt.edu/jounals/JT E/jte-v7n-1/gokhle.jte-v7n1. 2010.

Hook Petter and Vass Andy. Creating Winning Classrooms. David Fulton Publishers. 2010.

Johnson David W. \& Roger T. Johnson. Learning Together and Alone; Cooperative, Competitive, and Individualize Learning. New Jersey: Prentice Hall Inc. 2007

Kirk Roger E., Experiment Design, Procedures for the Behavioral Science. Belmont: California: Wadsworth Inc., 2010.

Learning, Six elements in Constructivist Classrooms. Corwin Press.Inc: California, 2009.

Paulus B Paul, Nijstad A. Bernard. Group Creativity: Innovation Through Collaboration. Oxford University Press 

JURNAL PENDIDIKAN USIA DINI

Volume 11 Edisi 1, April 2017 